\title{
BK Virus-Hemorrhagic Cystitis Following Allogeneic Stem Cell Transplantation: Clinical Characteristics and Utility of Leflunomide Treatment
}

\author{
Allojenik Kök Hücre Transplantasyonu Sonrası BK Virüs Hemorajik Sistiti: Klinik Özellikleri \\ ve Leflunomid Tedavisinin Etkisi
}

Young Hoon Park, Joo Han Lim, Hyeon Gyu Yi, Moon Hee Lee, Chul Soo Kim

Inha University Faculty of Medicine and Hospital, Department of Hematology-Oncology, Incheon, Republic of Korea

\section{Abstract}

Objective: BK virus-hemorrhagic cystitis (BKV-HC) is a potential cause of morbidity and mortality in patients having undergone allogeneic stem cell transplantation (Allo-SCT). We analyzed the clinical features of BKV-HC following Allo-SCT and reported the utility of leflunomide therapy for BKV-HC.

Materials and Methods: From January 2005 to June 2014, among the 69 patients that underwent Allo-SCT in our institution, the patients who experienced BKV-HC were investigated retrospectively.

Results: $\mathrm{HC}$ was observed in 30 patients (43.5\%), and among them, 18 of the cases $(26.1 \%)$ were identified as BKV-HC. The median age of the patients ( 12 males and 6 females) was 45 years (minimummaximum: 13-63). Patients received Allo-SCT for acute myeloid leukemia $(n=11)$, aplastic anemia $(n=4)$, myelodysplastic syndrome $(n=2)$, and non-Hodgkin lymphoma $(n=1)$. The donor types were human leukocyte antigen (HLA)-matched sibling donor for six patients, HLA-matched unrelated donor for nine, and haploidentical familial donor for two. The median onset and duration of BKV-HC was on day 21 after transplantation (minimum-maximum: 7-97) and 22 days (minimum-maximum: 6-107). Eleven patients (62.1\%) had grade I-II HC and seven patients (38.9\%) had grade III-IV (highgrade) $\mathrm{HC}$. Among the seven patients who had high-grade $\mathrm{HC}$, one had complete response, one had partial response, and five had no response. Among the five nonresponders, one died of BKV-HC associated complications. The remaining four patients were treated with leflunomide, achieving complete response $(n=2)$ and partial response $(n=2)$. The median duration from the start of leflunomide therapy to response was 13 days (minimum-maximum: 8-17 days). All patients tolerated the leflunomide treatment well, with three patients having mild gastrointestinal symptoms, including anorexia and abdominal bloating.

Conclusion: BKV-HC was commonly observed in patients with HC following Allo-SCT. In high-grade BKV-HC patients who do not respond to supportive care, leflunomide may be a feasible option without significant toxicity.

Keywords: BK virus, Hemorrhagic cystitis, Allogeneic stem cell transplantation, Leflunomide

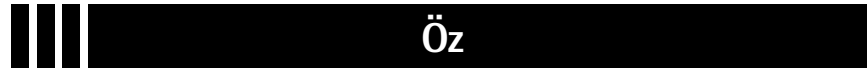

Amaç: BK-virüs hemorajik sistiti (BKV-HS) allojenik kök hücre nakli (Allo-KHN) uygulanan hastalarda morbidite ve mortalitenin önemli bir nedenidir. Bu çalışmada Allo-KHN sonrası BKV-HS olan olguların klinik özellikleri ve leflunomid tedavisinin BKV-HS'deki etkinliği araştırılmıştır.

Gereç ve Yöntemler: Kliniğimizde Ocak 2005-Haziran 2014 arası AlloKHN uygulanmış 69 hastada, BKV-HS geçirmiş olanlar retrospektif olarak değerlendirildi.

Bulgular: Otuz hastada $(\% 43,5)$ HS gözlendi. Bu olguların 18 'inde $(\% 26,1)$ BKV-HS'si saptandı. Hastaların (12'si erkek, altısı kadın) medyan yaşı 45 (13-63) idi. Hastalara akut miyeloid lösemi $(n=11)$, aplastik anemi $(n=4)$, miyelodisplastik sendrom $(n=2)$ ve non-Hodgkin lenfoma $(n=1)$ nedeni ile Allo-KHN uygulanmıştı. Altısında insan lökosit antijeni (ILA)-uygun kardeş, dokuzunda ILA-uygun akraba dışı donör ve ikisinde haplo-identik donör kullanılmıştı. Transplant sonrası BKV-HS medyan başlangıç zamanı 21 gün (7-97 gün), medyan süresi 22 gün (6-107 gün) idi. On bir olguda $(\% 62,1)$ derece I-II, yedi olguda $(\% 38,9)$ derece III-IV (yüksek derecede) HS saptandı. Yüksek derece HS'li yedi hastanın, birinde tam yanıt, birinde kısmi yanıt elde edilirken, beş hastada yanıt alınamadı. Yanıt alınmayan beş hastanın birisi BKV-HS ilişkili komplikasyonlardan kaybedildi. Geri kalan dört hasta leflunomid ile tedavi edildi. Bu hastaların ikisinde tam yanıt, ikisinde kısmi yanıt elde edildi. Leflunomidin başlangıcından itibaren medyan yanıt süresi 13 gündü (8-17 gün). Tüm hastalar leflunomidi iyi tolere ederken, üç hastada anoreksi ve abdominal gaz şikayetleri dahil hafif şiddetli gastrointestinal yan etkiler gözlendi.

Sonuç: Allo-KHN sonrası izlemde BKV-HS yaygın olarak gözlenmiştir. Destek tedavisine yanıt vermeyen yüksek derece BKV-HS'li olgularda leflunomid, anlamlı toksisitesi olmaksızın bir seçenek olabilir.

Anahtar Kelimeler: BK virüs, Hemorajik sistit, Allojenik kök hücre transplantasyonu, Leflunomid 


\section{Introduction}

Hemorrhagic cystitis ( $\mathrm{HC}$ ) is a potential cause of morbidity and mortality in patients that have undergone allogeneic stem cell transplantation (Allo-SCT) $[1,2,3]$. Its incidence ranges from $5 \%$ to $68 \%$ of Allo-SCT recipients, with severe-grade hematuria in $29 \%-44 \%$ of cases $[3,4,5,6,7]$. Variable etiologies for the development of $\mathrm{HC}$ in Allo-SCT recipients include noninfectious and infectious causes. As an infectious cause of $\mathrm{HC}, \mathrm{BK}$ virus$\mathrm{HC}$ (BKV-HC) occurs later after transplantation, usually in the post-engraftment period [3]. The BKV, a member of the family Polyomaviridae, is typically acquired in childhood and embedded in urothelial cells of the urinary tract in the latent dormant stage [8]. BKV reactivation is commonly associated with $\mathrm{HC}$ in Allo-SCT settings, occurring in $10 \%$ to $25 \%$ of patients [8]. The clinical symptoms of BKV-HC vary to a great extent in Allo-SCT recipients from asymptomatic hematuria to massive hemorrhage leading to urinary obstruction and renal failure $[2,9,10]$. Previous studies demonstrated that BKV-HC is associated with not only increased morbidity and but also increased mortality in Allo-SCT patients $[6,7,11,12]$, and studies have also defined potential risk factors for the development of BKV-HC $[4,5,13,14,15]$, most of which have not been observed consistently in several reports.

Leflunomide, an immunomodulatory agent with antiviral activity, has been found effective against cytomegalovirus (CMV), herpes simplex, and BKV based on in vitro data $[6,16,17]$. In renal allografts, leflunomide has been widely used to treat biopsy-proven BKV nephropathy $[18,19]$, but it has not been well studied in Allo-SCT settings. Only two reports showed satisfactory results of leflunomide therapy in the treatment of BKV-HC after Allo-SCT [20,21].

In this retrospective study, we report the incidence, severity, and outcome of clinical BKV-HC in patients who underwent Allo-SCT to treat variable hematologic diseases. Furthermore, we report high-grade BKV-HC patients who achieved favorable response to leflunomide therapy.

\section{Materials and Methods}

\section{Patients}

A total of 69 patients underwent Allo-SCT in our institution from January 2005, when BKV polymerase chain reaction (PCR) testing became clinically available, to June 2014. Baseline demographic and transplantation data were collected, including age, sex, underlying disease, conditioning regimen, stem cell source, donor type, prophylaxis to infection and graft-versus-host disease (GVHD), time to engraftment, presence and grade of GVHD, and survival at last follow-up. Patients received either myeloablative or reducedintensity conditioning regimen according to disease status, age, or comorbidities. As prophylaxis against $\mathrm{HC}$, hyperhydration (intravenous isotonic saline over $3 \mathrm{~L} / \mathrm{m}^{2}$ per day) with forced diuresis was used to prevent toxicity of conditioning regimen for Allo-SCT. In addition, for patients receiving a preparative regimen containing cyclophosphamide (Cy), 2-mercaptoethane sulfonate (MESNA) was given prior to the Cy administration and thereafter as a continuous infusion until the last dose of Cy. Acute GVHD and chronic GVHD were diagnosed and graded according to previously published criteria [22,23].

\section{Diagnosis of BK Virus-Hemorrhagic Cystitis}

$\mathrm{HC}$ was defined as the presence of sustained hematuria and urinary symptoms after the beginning of conditioning therapy in the absence of gynecological-related bleeding, generalized bleeding diathesis, and urinary tract infection. Severity of $\mathrm{HC}$ was graded according to the following criteria [7]: grade 0 (no hematuria), grade I (microscopic hematuria), grade II (macroscopic hematuria), grade III (macroscopic hematuria with presence of blood clots), and grade IV (macroscopic hematuria with clots and renal impairment due to urinary obstruction). Grades III and IV were defined as high-grade $\mathrm{HC}$. The date of onset of $\mathrm{HC}$ was defined as the first day of symptoms or laboratory evidence appearing after transplant. Routine urinalysis was performed at least twice a week during hospitalization and thereafter at outpatient visits. For patients who had urinary symptoms or gross hematuria, BKV testing by a qualitative PCR-based method was performed with the urine specimen to identify the presence of virus.

\section{BK Virus Polymerase Chain Reaction Test}

Each urine sample was submitted to DNA extraction using a OIAamp DNA Mini Kit (OIAGEN, Hilden, Germany) according to the manufacturer's instructions. A primer was designed for a highly conserved region of gene large T antigen to obtain a 160bp amplicon from the BKV genome using the GeneAmp 2720 Thermal Cycler (ABI, Foster City, CA, USA). PCR of urine for BKV viruria had a sensitivity of $90 \%$ and a specificity of $96.5 \%$ (cutoff value: 160 copies $/ \mathrm{mL}$ ).

\section{Urine Cytology}

Each urine specimen was processed for cytological evaluation by centrifugation. After removal of the supernatant, the sediment was examined for clarity. Cytospin slides were fixed in 95\% alcohol, stained by the Papanicolaou method, and observed for the presence of urine decoy cells (characterized by a groundglass appearance with an enlarged nucleus, which is occupied by a homogeneous basophilic inclusion surrounded by chromatin) by a well-trained pathologist.

\section{Treatment and Criteria of Response}

All patients diagnosed with BKV-HC received supportive treatment, including hyperhydration with normal saline, forced 
diuresis, urine alkalinization, analgesics, and blood transfusion to maintain platelet counts at $\geq 50 \times 109 / \mathrm{L}$ and a hemoglobin level of $\geq 8 \mathrm{~g} / \mathrm{dL}$. Foley catheterization and bladder irrigation were considered for patients with high-grade $\mathrm{HC}$ who had no response (NR) to supportive care. Leflunomide therapy was indicated as follows: 1) grade III-IV HC; 2) no change or worsening in urinary symptoms or grade of hematuria during supportive care within 2 weeks; 3) no abnormality in liver function tests; 4) absolute neutrophil count of $>1.0 \times 109 / \mathrm{L}$; and 5) no abnormality on chest radiology. For the patients receiving leflunomide therapy, leflunomide at $100 \mathrm{mg} /$ day orally was used as a loading dose for 5 days, followed by maintenance doses of $20 \mathrm{mg} /$ day until resolution of hematuria and urinary symptoms. Clinical response was defined as follows: complete response (CR), completely improved in symptoms with absence of hematuria; partial response (PR), downgrading of severity with persistent hematuria; NR, unchanged or worsening urinary symptoms or grade of hematuria; refractoriness, NR even after about 2 weeks of supportive care. The response was evaluated after 20 days of leflunomide treatment.

\section{Statistical Analysis}

The cumulative incidence of BKV-HC was estimated with the interval starting at Allo-SCT until the day of the first PCRpositive urine sample. The Mann-Whitney test and chi-square test were used for comparisons for continuous and categorical data, respectively, between the patients with low-grade BKV-HC and those with high-grade BKV-HC. Univariate and multivariate analyses of risk factors for BKV-HC occurrence were performed using the Cox proportional hazard model. SPSS 14.0 (SPSS Inc., Chicago, IL, USA) was used for all statistical analyses, and all were two-sided. Statistical significance was defined as $p<0.05$. This study was approved by the Institutional Review Board of the Inha University Hospital.

\section{Results}

\section{Patient Characteristics and Transplant Outcome}

The demographic characteristics of the $\mathrm{HC}$ patients are presented in Table 1. In our study, a total of 30 of 69 (43.5\%) patients who underwent Allo-SCT developed HC. Of these, 18 (26.1\%) were diagnosed with BKV-HC and were included in this study. Seven (38.9\%) patients received antithymoglobulin for in vivo T-cell depletion. Nine patients (50\%) had acute GVHD, and two patients (11.1\%) had grade III-IV GVHD. These two patients received systemic glucocorticoid therapy $(1-2 \mathrm{mg} / \mathrm{kg}$ prednisone) without additional immunosuppressant agents and showed a good response to steroid therapy. Twelve patients (66.7\%) had chronic GVHD, and seven patients (38.9\%) showed extensive chronic GVHD. Among the seven patients with extensive GVHD, two patients showed corticosteroid-refractory chronic GVHD and were treated with mycophenolate mofetil, but failed to respond.

\section{Clinical Features of BK Virus-Hemorrhagic Cystitis}

The clinical characteristics of BKV-HC are detailed in Table 2. Eleven patients (62.1\%) had low-grade $\mathrm{HC}$ and seven patients $(38.9 \%)$ had high-grade HC. The median onset and duration of BKV-HC was on day 21 (minimum-maximum: 7-97) after transplantation and 22 days (minimum-maximum: 6-107), respectively. There was no significant difference between the onset in patients with low-grade $\mathrm{HC}$ or high-grade $\mathrm{HC}(21$ vs. 21 days, $\mathrm{p}=0.633)$. In two patients (11.1\%), BKV-HC developed before neutrophil engraftment. Nine $(50.0 \%)$ patients had concomitant cytomegalovirus viremia, and among them, four patients received ganciclovir treatment. Of patients with acute GVHD ( $n=9)$, seven (77.7\%) developed acute GVHD after onset of BKV-HC and, conversely, two (22.3\%) developed BKV-HC after the diagnosis of acute GVHD. Four (22\%) patients had urinary cytologic changes compatible with BKV.

\section{Treatment}

The majority of the patients received supportive treatment, including intravenous hydration and/or blood transfusion (Table 2). A urinary catheter was inserted for three patients with $\mathrm{HC}$ of grade III and two patients with HC of grade IV. We slightly tapered the immunosuppressant by monitoring the serum trough level in low-grade BKV-HC patients with no evidence of GVHD or grade I-II GVHD. In contrast, in the patients with high-grade BKV-HC, reduction or withdrawal of the immunosuppressant was not done as a treatment option for BKV-HC due to the risk of GVHD. After supportive care, nine patients (50.0\%) achieved $C R$, four patients (22.2\%) PR, and five patients (27.8\%) NR. All patients with low-grade $\mathrm{HC}$ showed better responses than PR to supportive treatment. Out of the seven patients who had highgrade $H C$, one had $C R$, one $P R$, and five NR. Response ( $C R+P R)$ rate in patients with low-grade $\mathrm{HC}$ was significantly higher than in those with high-grade $\mathrm{HC}(100 \%$ vs. $28.6 \%, \mathrm{p}=0.004)$. Among the five nonresponders, one died of BKV-HC-associated renal failure with no evidence of progression of underlying disease. The remaining four patients were treated with oral leflunomide as salvage therapy.

\section{Risk Factors for BK Virus-Hemorrhagic Cystitis Occurrence}

In univariate analysis, HLA mismatching and acute GVHD grades II-IV were associated with a higher risk of developing BKV-HC $(p=0.034$ and $p<0.001$, respectively). In multivariate analysis, only acute GVHD grades II-IV were independent risk factors for BKV-HC (hazard ratio $3.26,95 \% \mathrm{Cl} 1.42-13.5, \mathrm{p}=0.002$ ) in this study (Table 3). 


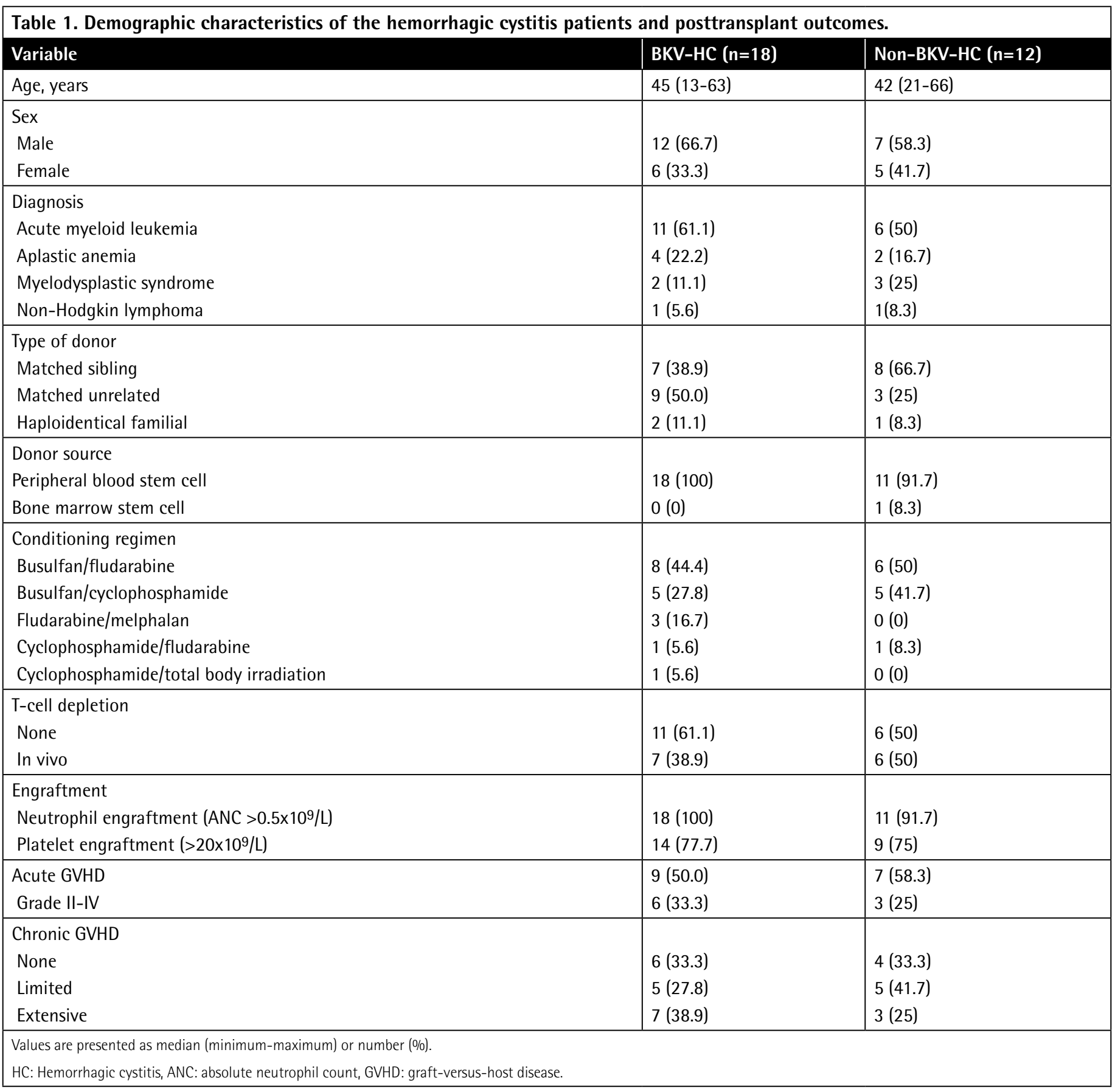

\section{Leflunomide Therapy}

Detailed information about the four patients receiving leflunomide therapy is summarized in Table 4. Of the four patients, three had acute myeloid leukemia and one had highrisk myelodysplastic syndrome. All patients had acute GVHD before development of BKV-HC. After leflunomide treatment, two (50\%) patients achieved CR and two (50\%) achieved PR. One CR patient and one PR patient had a negative PCR for $B K V$, but BKV in urine still remained detectable in one patient achieving CR. The median duration from the start of leflunomide therapy to response was 13 days (minimum-maximum: 8-17).
The dose of leflunomide was not reduced for any patients. All patients tolerated the leflunomide treatment well, with three patients having mild gastrointestinal symptoms, including anorexia and abdominal bloating. No significant adverse effects, such as hepatotoxicity, skin reactions, diarrhea, bone marrow suppression, or pneumonia, were observed during leflunomide treatment. There was no recurrence of hematuria in the two patients achieving $\mathrm{CR}$ after discontinuation of leflunomide therapy. Of the patients achieving PR, one died of leukemia relapse 16.3 months after Allo-SCT. The remaining three patients are still alive without hematuria. 


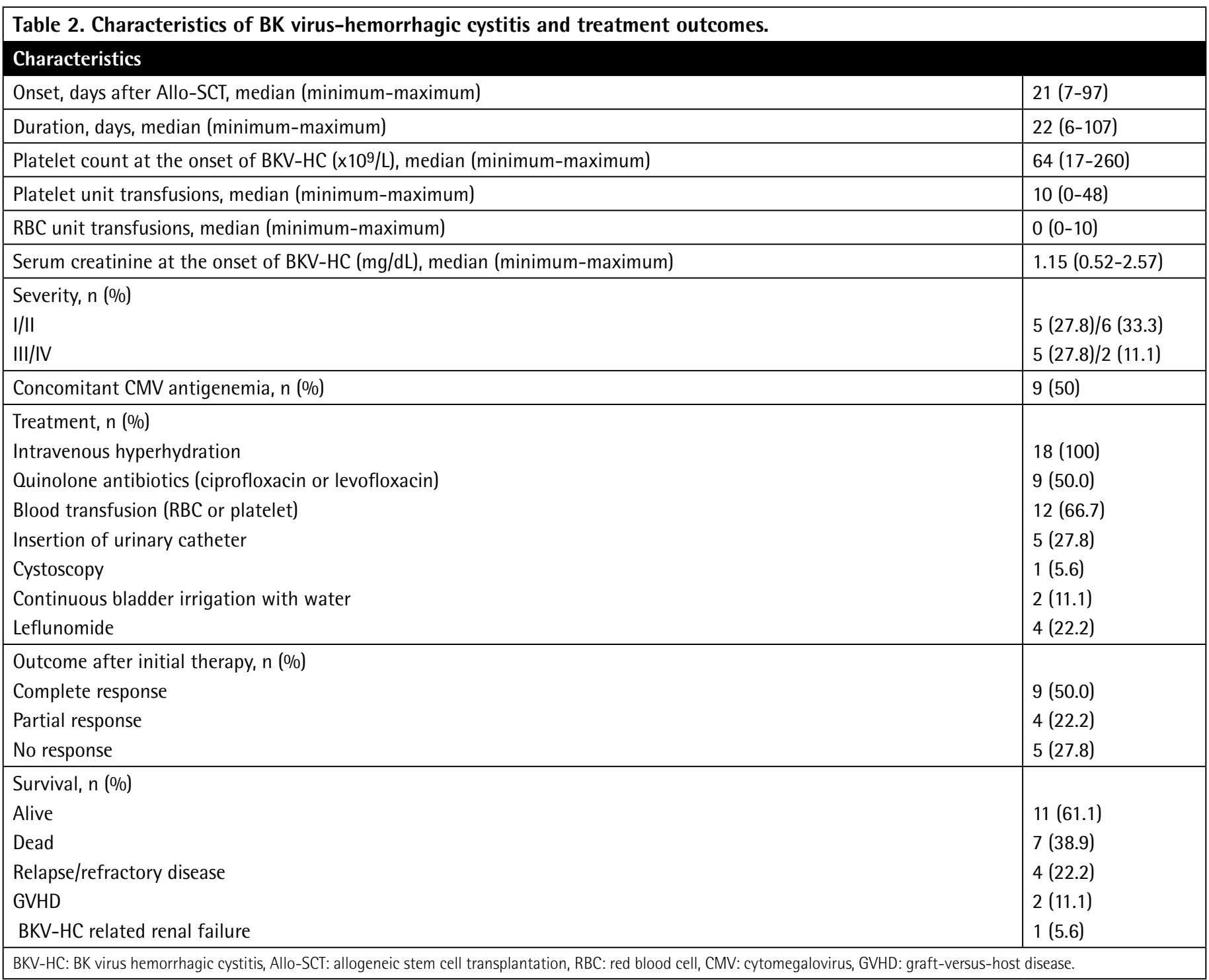

\section{Table 3. Univariate and multivariate analysis for development of BK virus hemorrhagic cystitis.}

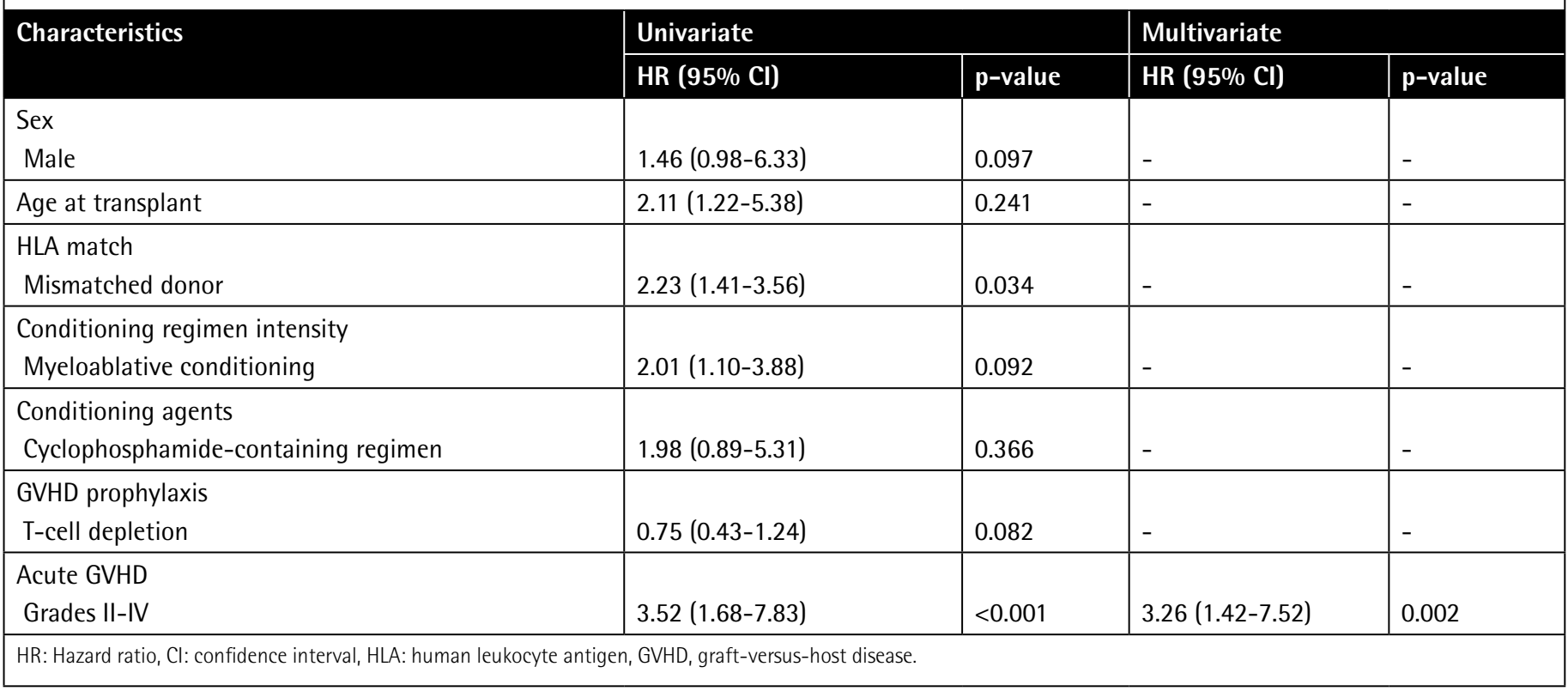




\begin{tabular}{|l|l|l|l|l|}
\hline \multicolumn{2}{|l}{ Table 4. Clinical characteristics of the patients receiving leflunomide therapy. } \\
\hline & Patient 1 & Patient 2 & Patient 3 & Patient 4 \\
\hline Age (years)/Sex & $40 / \mathrm{M}$ & $49 / \mathrm{M}$ & $50 / \mathrm{F}$ & 52/M \\
\hline Diagnosis & AML & AML & MDS & AML \\
\hline Donor type & MSD & MSD & MUD & MSD \\
\hline Conditioning & Bu/Flu & Bu/Flu & Bu/Flu & Bu/Cy \\
\hline GVHD prophylaxis & CsA/MTX & CsA/MTX & CSA/MTX & CsA/MTX \\
\hline T-cell depletion & No & No & Yes & No \\
\hline Onset of BKV-HC (days) & 24 & 21 & 19 & 23 \\
\hline Severity of HC & Grade III & Grade III & Grade III & Grade III \\
\hline Acute GVHD & Grade II (skin) & Grade II (skin, liver) & Grade I (skin) & Grade II (skin) \\
\hline Chronic GVHD & Extensive & Extensive & Extensive & Limited \\
\hline CMV antigenemia & No & Yes & No & No \\
\hline Response after therapy & CR & PR & PR & CR \\
\hline PCR positivity for BKV after therapy & Positive & Negative & Positive & Negative \\
\hline Adverse effects & Nausea (mild) & Nausea (mild) & Abdominal bloating & None \\
\hline Duration to response (days) & 8 & 14 & 12 & 17 \\
\hline Outcome & Alive & $\begin{array}{l}\text { Dead (due to leukemia } \\
\text { relapse) }\end{array}$ & Alive & Alive \\
\hline $\begin{array}{l}\text { M: Male, F: female, AML: acute myeloid leukemia, MDS: myelodysplastic syndrome, MSD: matched sibling donor, MUD: matched unrelated donor, Bu: busulfan, Flu: fludarabine, Cy: } \\
\text { cyclophosphamide, CSA: cyclosporine, MTX: methotrexate, Allo-SCT: allogeneic stem cell transplantation, BKV-HC: BK virus hemorrhagic cystitis, GVHD: graft-versus-host disease, } \\
\text { CMV: cytomegalovirus, CR: complete response, PR: partial response, PCR: polymerase chain reaction. }\end{array}$ \\
\hline
\end{tabular}

\section{Discussion}

Our results, with an overall incidence of HC following Allo-SCT of $43.5 \%$, are consistent with other studies' findings, which reported frequencies of $\mathrm{HC}$ following SCT ranging from 5\% to $68 \%[3,4,5,6,7]$. BKV was identified in $60.0 \%$ of cases (18 of 30 patients) by a qualitative PCR-based assay. A study of 22 Allo-SCT patients who experienced HC showed that the most frequent virus detected was BKV, with an incidence of 54.5\% of patients, followed by JC virus and CMV [24]. In a study of 102 children who underwent Allo-SCT for malignancies and nonmalignant diseases, $\mathrm{HC}$ occurred in 26 patients (25.5\%), and among them, BKV was identified in $21(80.8 \%)$ patients [25]. These findings demonstrated that $\mathrm{HC}$ is a frequent complication after Allo-SCT and BKV is mainly responsible for HC in Allo-SCT recipients.

Hemorrhagic cystitis after SCT frequently caused prolongation of hospitalization and occasionally death $[10,24,26]$. Gilis et al. demonstrated that the median duration of hospitalization for Allo-SCT was significantly longer for patients developing BKV-HC compared with those without BKV-HC (50 vs. 40 days, $p<0.001$ ) [26]. In addition, in a series of 12 patients with BKV$\mathrm{HC}, \mathrm{HC}$-associated renal failure was the main cause of death in two $(16.7 \%)$ patients, who failed to respond to any treatment including administration of intravenous cidofovir [24]. In our study, among the seven high-grade BKV-HC patients, one died of BKV-HC-related renal failure. These observations suggest that prompt alternative treatment should be considered in patients with BKV-HC, and especially high-grade $\mathrm{HC}$, who had refractoriness to initial supportive treatment.

Currently, there is no established antiviral drug for the treatment of $\mathrm{BKV}-\mathrm{HC}$, although reduction in immunosuppression is necessary for clearance of the BKV. Salvage treatment with antiviral agents, including cidofovir, leflunomide, and fluoroquinolones, has been considered in renal transplant recipients when reduction of immunosuppression alone could not improve renal function, with no antiviral agents shown to be effective in randomized controlled studies $[18,27,28,29]$. In Allo-SCT settings, prior reports showed that treatment with varying doses of cidofovir, having activity against CMV, adenovirus, and polyomaviruses, was feasible $[30,31,32]$. However, the potential nephrotoxicity of cidofovir, resulting in direct tubular toxicity, still remains a major obstacle to its use. Leflunomide, an immunomodulatory agent, has modest antipolyomavirus activity in vitro, although the precise mechanism of action remains to be fully understood $[6,17]$. In renal transplant patients, leflunomide has been used to treat BKV nephropathy, resulting in a significant decline in the BK viral load with relatively stable renal function without the toxicity of leflunomide $[10,18]$. Thus far, there are limited clinical data on the utility of leflunomide therapy in the treatment of BKV-HC patients in Allo-SCT settings. In a series of 14 adult patients with BKV-HC undergoing Allo-SCT, leflunomide therapy showed favorable results for BKV-HC treatment with no serious adverse effects, with CR and PR being seen in 50\% and 37.5\% 
of patients, respectively [21]. In a pilot study with five pediatric patients with severe BKV-HC after Allo-SCT, significantly shorter duration of BKV-HC $(p<0.01)$ and decreased BK viral loads in blood $(p<0.01)$ and urine $(p=0.03)$ were observed after leflunomide therapy compared with historical controls [20]. In this study, CR was achieved in 50\% of the patients receiving leflunomide therapy. In addition, potential adverse effects associated with leflunomide treatment, including hepatotoxicity and bone marrow suppression, were not observed in any treated patients. Our results were similar to previous reports regarding leflunomide therapy in adult patients. These data suggest that leflunomide is effective in the treatment of posttransplant highgrade BKV-HC, especially in cases refractory to supportive care.

This study has potential limitations, mostly stemming from its small sample size and retrospective design. Several studies have indicated that $\mathrm{BK}$ viruria was quantitatively related to the occurrence of HC after Allo-SCT and clinical response to antiviral therapy may be linked with reduction of viral loads in blood and/or urine $[20,21,26,33]$. However, we performed only a qualitative test in urine samples, but BKV was still detectable in one patient achieving CR after leflunomide therapy, suggesting that complete clearance of the virus in urine may not be necessary in BKV-HC patients treated with leflunomide.

In summary, BKV-HC is a common complication of Allo-SCT and is associated with significant morbidity, especially in high-grade BKV-HC. In high-grade BKV-HC patients who fail to respond to supportive care, leflunomide therapy may be a feasible treatment option without significant toxicity. Prospective randomized controlled trials are warranted to evaluate the efficacy and safety of leflunomide in the treatment of BKV-HC after Allo-SCT.

\section{Ethics}

Ethics Committee Approval: This study was approved by the Institutional Review Board of the Inha University Hospital; Informed Consent: It was taken.

\section{Authorship Contributions}

Surgical and Medical Practices: Young Hoon Park, Hyeon Gyu Yi, Chul Soo Kim; Concept: Young Hoon Park, Chul Soo Kim; Design: Young Hoon Park, Chul Soo Kim; Data Collection or Processing: Young Hoon Park, Joo Han Lim, Hyeon Gyu Yi, Moon Hee Lee, Chul Soo Kim; Analysis or Interpretation: Young Hoon Park, Joo Han Lim, Hyeon Gyu Yi, Moon Hee Lee; Literature Search: Young Hoon Park, Joo Han Lim, Hyeon Gyu Yi, Moon Hee Lee, Chul Soo Kim; Writing: Young Hoon Park, Joo Han Lim, Hyeon Gyu Yi, Moon Hee Lee, Chul Soo Kim.

Conflict of interest: The authors of this paper have no conflicts of interest, including specific financial interests, relationships, and/or affiliations relevant to the subject matter or materials included.

\section{References}

1. Gargiulo G, Orlando L, Alberani F, Crabu G, Di Maio A, Duranti L, Errico A, Liptrott S, Pitrone R, Santarone S, Soliman C, Trunfio A, Selleri C, Bruno B, Mammoliti $S$, Pane F. Haemorrhagic cystitis in haematopoietic stem cell transplantation (HSCT): a prospective observational study of incidence and management in HSCT centres within the GITMO network (Gruppo Italiano Trapianto Midollo Osseo). Ecancermedicalscience 2014;8:420.

2. Siguier $M$, Sellier P, Bergmann JF. BK-virus infections: a literature review. Med Mal Infect 2012;42:181-187.

3. Yang CC, Hurd DD, Case LD, Assimos DG. Hemorrhagic cystitis in bone marrow transplantation. Urology 1994;44:322-328.

4. Yaghobi R, Ramzi M, Dehghani S. The role of different risk factors in clinical presentation of hemorrhagic cystitis in hematopoietic stem cell transplant recipients. Transplant Proc 2009;41:2900-2902.

5. Sencer SF, Haake RJ, Weisdorf DJ. Hemorrhagic cystitis after bone marrow transplantation. Risk factors and complications. Transplantation 1993;56:875-879.

6. Dropulic LK, Jones RJ. Polyomavirus BK infection in blood and marrow transplant recipients. Bone Marrow Transplant 2008;41:11-18.

7. Bedi A, Miller CB, Hanson JL, Goodman S, Ambinder RF, Charache P, Arthur RR, Jones RJ. Association of BK virus with failure of prophylaxis against hemorrhagic cystitis following bone marrow transplantation. J Clin Oncol 1995;13:1103-1109.

8. dela Cruz J, Pursell K. BK virus and its role in hematopoietic stem cell transplantation: evolution of a pathogen. Curr Infect Dis Rep 2014;16:417.

9. Raval M, Gulbis A, Bollard C, Leen A, Chemaly R, Shpall E, Lahoti A, Kebriaei $P$. Evaluation and management of BK virus-associated nephropathy following allogeneic hematopoietic cell transplantation. Biol Blood Marrow Transplant 2011;17:1589-1593.

10. Pahari A, Rees L. BK virus-associated renal problems--clinical implications. Pediatr Nephrol 2003;18:743-748.

11. Arthur RR, Shah KV, Baust SJ, Santos GW, Saral R. Association of BK viruria with hemorrhagic cystitis in recipients of bone marrow transplants. N Engl J Med 1986;315:230-234.

12. Razonable RR, Eid AJ. Viral infections in transplant recipients. Minerva Med 2009;100:479-501.

13. Leung $A Y$, Mak $R$, Lie $A K$, Yuen $K Y$, Cheng VC, Liang $R$, Kwong $Y L$. Clinicopathological features and risk factors of clinically overt haemorrhagic cystitis complicating bone marrow transplantation. Bone Marrow Transplant 2002;29:509-513.

14. Mori $Y$, Miyamoto $T$, Kato $K$, Kamezaki K, Kuriyama T, Oku S, Takenaka K, Iwasaki H, Harada N, Shiratsuchi M, Abe Y, Nagafuji K, Teshima T, Akashi K. Different risk factors related to adenovirus- or BK virus-associated hemorrhagic cystitis following allogeneic stem cell transplantation. Biol Blood Marrow Transplant 2012;18:458-465.

15. Rorije NM, Shea MM, Satyanarayana G, Hammond SP, Ho VT, Baden LR Antin JH, Soiffer RJ, Marty FM. BK virus disease after allogeneic stem cell transplantation: a cohort analysis. Biol Blood Marrow Transplant 2014;20:564-570.

16. Zaman RA, Ettenger RB, Cheam $H$, Malekzadeh MH, Tsai EW. A novel treatment regimen for BK viremia. Transplantation 2014;97:1166-1171.

17. Farasati NA, Shapiro $R$, Vats $A$, Randhawa P. Effect of leflunomide and cidofovir on replication of BK virus in an in vitro culture system. Transplantation 2005;79:116-118.

18. Leca $\mathrm{N}$. Leflunomide use in renal transplantation. Curr Opin Organ Transplant 2009;14:370-374.

19. Josephson MA, Gillen $D$, Javaid $B$, Kadambi $P$, Meehan $S$, Foster $P$, Harland R, Thistlethwaite RJ, Garfinkel M, Atwood W, Jordan J, Sadhu M, Millis MJ, Williams J. Treatment of renal allograft polyoma BK virus infection with leflunomide. Transplantation 2006;81:704-710. 
20. Wu KH, Weng T, Wu HP, Peng CT, Sheu JN, Chao YH. Effective treatment of severe BK virus-associated hemorrhagic cystitis with leflunomide in children after hematopoietic stem cell transplantation: a pilot study. Pediatr Infect Dis J 2014;33:1193-1195.

21. Chen XC, Liu T, Li JJ, He C, Meng WT, Huang R. Efficacy and safety of leflunomide for the treatment of BK virus-associated hemorrhagic cystitis in allogeneic hematopoietic stem cell transplantation recipients. Acta Haematol 2013;130:52-56.

22. Przepiorka D, Anderlini P, Saliba R, Cleary K, Mehra R, Khouri I, Huh YO, Giralt S, Braunschweig I, van Besien K, Champlin R. Chronic graft-versushost disease after allogeneic blood stem cell transplantation. Blood 2001;98:1695-1700.

23. Przepiorka $D$, Weisdorf $D$, Martin $P$, Klingemann HG, Beatty $P$, Hows J, Thomas ED. 1994 Consensus conference on acute GVHD grading. Bone Marrow Transplant 1995;15:825-828.

24. Kim SY, Lee JW, Lee KM, Cho BS, Eom KS, Kim YJ, Lee $S$, Min CK, Kim HJ, Cho SG, Kim DW, Min WS, Kim CC. Viruria in adult hemorrhagic cystitis patients following allogeneic hematopoietic stem cell transplantation and implication of antiviral treatment. Korean J Hematol 2007;42:114-121.

25. Gorczynska E, Turkiewicz D, Rybka K, Toporski J, Kalwak K, Dyla A, Szczyra $Z$, Chybicka A. Incidence, clinical outcome, and management of virusinduced hemorrhagic cystitis in children and adolescents after allogeneic hematopoietic cell transplantation. Biol Blood Marrow Transplant 2005;11:797-804.

26. Gilis L, Morisset S, Billaud G, Ducastelle-Lepretre $S$, Labussiere-Wallet $H_{\text {, }}$ Nicolini FE, Barraco F, Detrait $M$, Thomas $X$, Tedone $N$, Sobh $M$, Chidiac C, Ferry T, Salles G, Michallet M, Ader F; Lyon BK Virus Study Group. High burden of BK virus-associated hemorrhagic cystitis in patients undergoing allogeneic hematopoietic stem cell transplantation. Bone Marrow Transplant 2014;49:664-670.

27. Vats $A$, Shapiro $R$, Singh Randhawa $P$, Scantlebury V, Tuzuner A, Saxena M, Moritz ML, Beattie TJ, Gonwa T, Green MD, Ellis D. Quantitative viral load monitoring and cidofovir therapy for the management of BK virus-associated nephropathy in children and adults. Transplantation 2003;75:105-112.

28. Kadambi PV, Josephson MA, Williams J, Corey L, Jerome KR, Meehan SM, Limaye AP. Treatment of refractory BK virus-associated nephropathy with cidofovir. Am J Transplant 2003;3:186-191.

29. Thamboo TP, Jeffery KJ, Friend PJ, Turner GD, Roberts IS. Urine cytology screening for polyoma virus infection following renal transplantation: the Oxford experience. J Clin Pathol 2007;60:927-930.

30. Gonzalez-Fraile MI, Canizo C, Caballero D, Hernandez R, Vazquez L, Lopez C, Izarra A, Arroyo JL, de la Loma A, Otero MJ, San Miquel JF. Cidofovir treatment of human polyomavirus-associated acute haemorrhagic cystitis. Transpl Infect Dis 200;3:44-46.

31. Held TK, Biel SS, Nitsache A, Kurth A, Chen S, Gelderblom HR, Sieqert W. Treatment of BK virus-associated hemorrhagic cystitis and simultaneous CMV reactivation with cidofovir. Bone Marrow Transplant 2000;26:347-350.

32. Hatakeyama N, Suzuki N, Kudoh T, Hori T, Mizue N, Tsutsumi H. Successful cidofovir treatment of adenovirus-associated hemorrhagic cystitis and renal dysfunction after allogenic bone marrow transplant. Pediatr Infect Dis J 2003;22:928-929.

33. Leung AY, Suen CK, Lie AK, Liang RH, Yuen KY, Kwong YL. Quantification of polyoma BK viruria in hemorrhagic cystitis complicating bone marrow transplantation. Blood 2001;98:1971-1978. 